\title{
Scratch
}

\section{Pemrograman Visual untuk Semuanya}

\author{
Seng Hansun \\ Program Studi Teknik Informatika, Universitas Multimedia Nusantara, Tangerang, Indonesia \\ hansun@umn.ac.id \\ Diterima 31 Mei 2014 \\ Disetujui 16 Juni 2014
}

\begin{abstract}
In this modern era, the need to have a more tinkerable, more meaningful, and more social programming language has arisen. One of the programming environments that catch up with this issue is Scratch.

In this paper, the author tries to explain Scratch as a visual programming language, its' basic concepts, and its' implementations. As an example, one interactive game that has been built using Scratch is shown at the end of this paper.
\end{abstract}

Index terms-game, Scratch, visual programming

\section{Pendahuluan}

Scratch merupakan suatu bahasa pemrograman baru yang memudahkan Anda dalam membuat cerita interaktif, game interaktif, dan animasi, serta membagikan karya kreasi Anda kepada orang lainnya melalui sarana internet [1]. Scratch membantu anakanak muda untuk berpikir secara kreatif, menalar secara sistematis, dan bekerja secara kolaboratif, yang merupakan keahlian mendasar yang dibutuhkan oleh semua orang saat ini.

Scratch didesain dengan tujuan pembelajaran dan pemahaman. Beragam pendidik telah bergabung dan mendukung pengembangan Scratch sejak 2007, baik dalam lingkungan formal maupun non formal, seperti K-12 classroom teachers, peneliti Ilmu Komputer, pustakawan, pendidik sejarah museum, dan para orang tua [2]. Para pendidik ini tergabung dalam sebuah komunitas online yang disebut sebagai ScratchEd, yang diluncurkan pada Juli 2009, dan menjadi tempat berbagi kisah pengalaman, pertukaran sumber data dan pertanyaan, serta mencari orang. Semua orang dapat bergabung dalam komunitas online tersebut secara gratis melalui tautan http://scratched.media. mit.edu/ [3].

Dalam disertasinya, Brennan [4] menyatakan bahwa dewasa ini kita hidup dalam budaya komputasional, yakni suatu budaya dimana manusia dikelilingi oleh sistem-sistem dan antarmuka komputasional, mulai dari jejaring sosial hingga infrastruktur perbankan, industri hiburan, dan sistem transportasi. Beliau menggunakan pendekatan kualitatif untuk menelusuri pembelajaran dalam budaya komputasional, mempelajari bagaimana lingkungan bahasa pemrograman Scratch dan komunitas online-nya dapat diterapkan guna mendukung proses pembelajaran baik di dalam maupun di luar sekolah. Dalam penutup disertasinya, beliau meninjau kesempatan dan tantangan yang akan dihadapi oleh anak muda dan para pendidik dalam tiga perspektif, yakni sebagai seorang peneliti, seorang desainer, dan seorang pembelajar, yang mengarah pada kesimpulan pentingnya penerapan Scratch dalam budaya komputasional dewasa ini.

Pada makalah ini akan dijabarkan secara singkat seluk beluk Scratch sebagai bahasa pemrograman visual, pemanfaatan dan cara penerapannya. Selain itu, salah satu contoh permainan interaktif Ping Pong yang dikembangkan oleh kingminer29 - salah seorang Scratcher, istilah yang umum digunakan untuk merujuk pada programmer Scratch - juga ditampilkan di sini.

\section{Scratch}

Scratch merupakan bahasa pemrograman visual yang dikembangkan oleh Lifelong Kindergarten research group di MIT Media Lab [5]. Pengembangan Scratch didukung oleh pendanaan dari National Science Foundation, Microsoft, Intel Foundation, Nokia, dan MIT Media Lab research consortia [1]. Pada bab ini, akan dijelaskan perkembangan Scratch selama ini, antarmuka, dan blok pembangunan Scratch sebagai pengenalan dalam Scratch programming.

\section{A. Perkembangan Scratch}

Pengembangan Scratch dimulai sejak tahun 2003 yang dikepalai oleh Mitch Resnick, dan telah melalui beberapa versi perkembangan, sebagai berikut $[6,7]$.

1. Scratch 1.0

Dirilis pada 8 Januari 2007 dan merupakan versi Scratch pertama yang tersedia untuk umum. Beberapa perubahan dari versi beta meliputi block Next Costume, Next Background, Think(), 
Think() for () Secs, Stop All Sounds, Forever If(); tombol baru untuk membuat sprites, kemampuan untuk berbagi projects secara online, perubahan ekstensi file dari .scratch menjadi .sb, dukungan beberapa bahasa, tombol Enter sebagai shortcut untuk Green Flag, dan kemampuan Import project.

2. Scratch 1.1

Dirilis secara resmi pada Mei 2007, dengan penambahan fitur baru berupa installer Windows yang baru, block Repeat Until (), bentuk Cap Block diperkenalkan, satu sprite dapat memainkan beberapa notes sekaligus, menambahkan tags untuk projects yang di-sharing, dan sebagainya.

3. Scratch 1.2

Merupakan rilis terakhir untuk Windows 98 dan ME, yang dirilis pada 7 Desember 2007. Beberapa fitur baru yang diperkenalkan adalah block Rest for () beats, kompresi gambar yang lebih baik, perbaikan beberapa sample projects, dan perubahan antarmuka di Paint Editor.

4. Scratch 1.3

Dirilis pada 2 September 2008, dengan beberapa fitur baru seperti Variables dapat menangani strings, Lists, Comments, penggunaan fonts dari komputer user, dan block If () Then, Repeat, Forever secara otomatis melingkupi block stacks lainnya.

5. Scratch 1.4

Dirilis secara resmi pada 19 Juli 2009, dengan fitur-fitur tambahan seperti blocks baru untuk penanganan string, block Ask () and Wait, block () Contains (), pemanfaatan webcam untuk mengambil gambar, dan sebagainya.

6. Scratch 2.0

Scratch 2.0 dikembangkan selama beberapa tahun hingga versi beta-nya diperkenalkan pada 28 Januari 2013. Versi resminya dirilis pada 9 Mei 2013, dengan beberapa fitur baru seperti UI yang baru, Procedures, Cloning, Cloud data, Vector graphics, Sound editor, dan sebagainya.

Sejak diperkenalkan kepada umum pada 2007, terdapat 5.619 .530 projects yang telah dibagikan, 3.387.470 user yang teregister, 27.229.307 komentar yang di-post, dan 440.857 studios yang dibangun [8]. Grafik 1 dan 2 menunjukkan statistik aktivitas user sebagaimana yang direkam dalam situs resmi Scratch, yang memperlihatkan jumlah projects, users, dan komentar yang diberikan.
Sementara itu, dari gambar 3 terlihat bahwa distribusi umur Scratcher baru paling banyak berasal dari anak-anak remaja dengan rentang usia 10-20 tahun. Hal ini memperlihatkan bahwa Scratch berhasil menarik minat para anak remaja untuk mempelajari bahasa pemrograman ini. Distribusi penyebaran Scratchers di dunia secara luas juga diperlihatkan pada Gambar 4 dengan intensitas jumlahnya masingmasing.

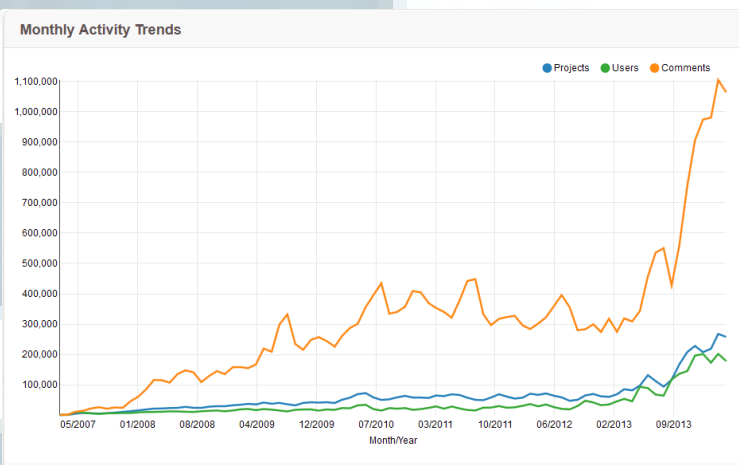

Gambar 1. Tren aktivitas situs Scratch [8]

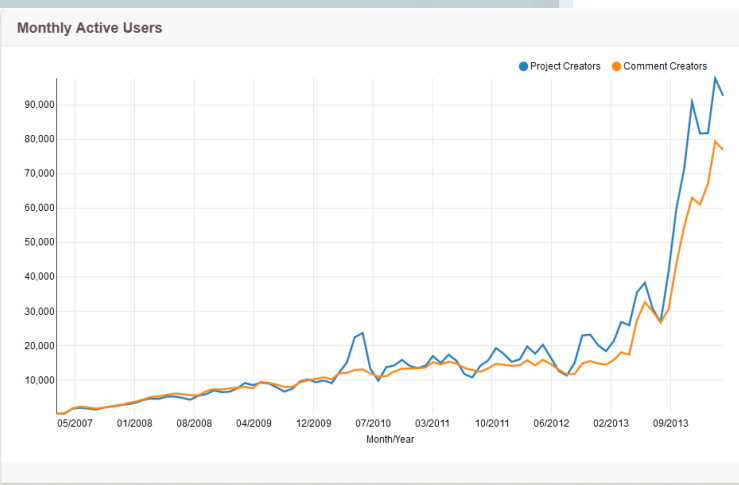

Gambar 2. User aktif [8]

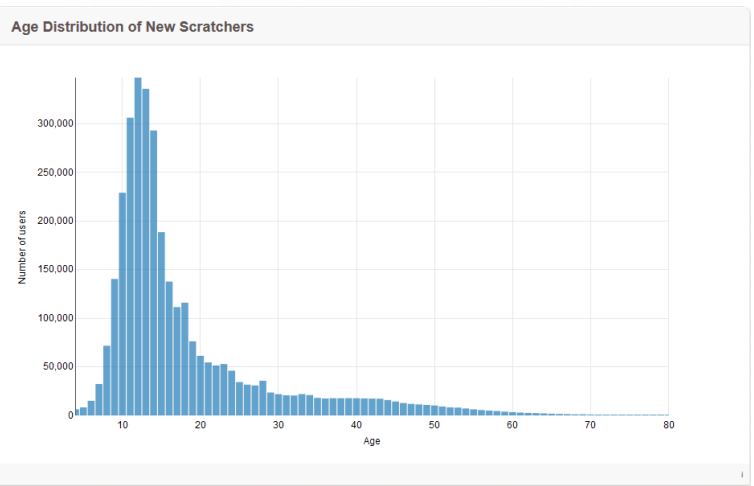

Gambar 3. Distribusi umur Scratchers baru [8] 


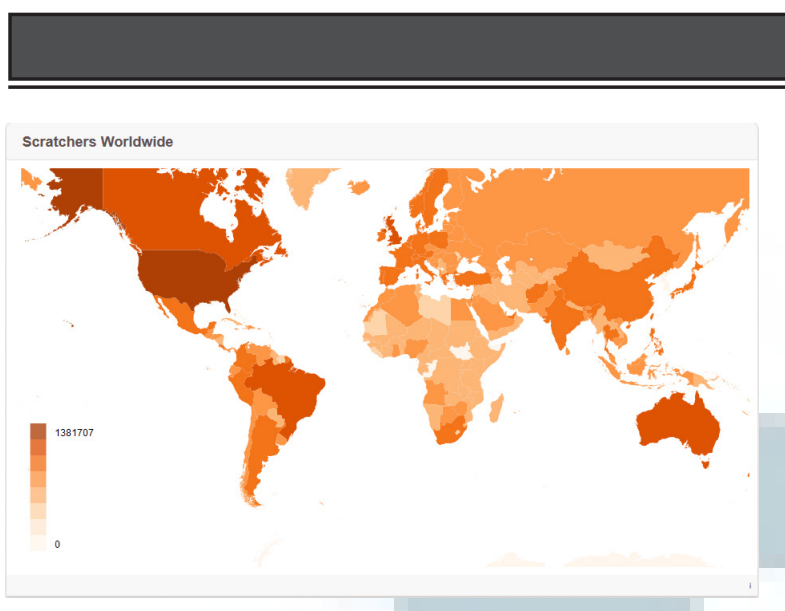

Gambar 4. Distribusi Scratchers dunia [8]

B. Antarmuka Scratch

Sebelum mempelajari Scratch, perlu diketahui antarmuka bahasa pemrograman visual Scratch terlebih dahulu. Beberapa hal yang perlu diketahui, antara lain [9]:

1. Stage

2. New Sprites

3. Sprite List
4. Blocks Palette dan Scripts Area

5. Costumes

6. Sounds

7. Current Sprite Info

8. Rotation Style

9. Toolbar

10. Menu

11. Green Flag

12. Paint Editor

Gambar 5 di bawah memperlihatkan antarmuka Scratch beserta komponen-komponennya seperti yang disebutkan di atas. Sementara gambar 6 memperlihatkan antarmuka Paint Editor Scratch yang dapat dimanfaatkan untuk mengubah costumes dan backgrounds yang digunakan dalam project Scratch.

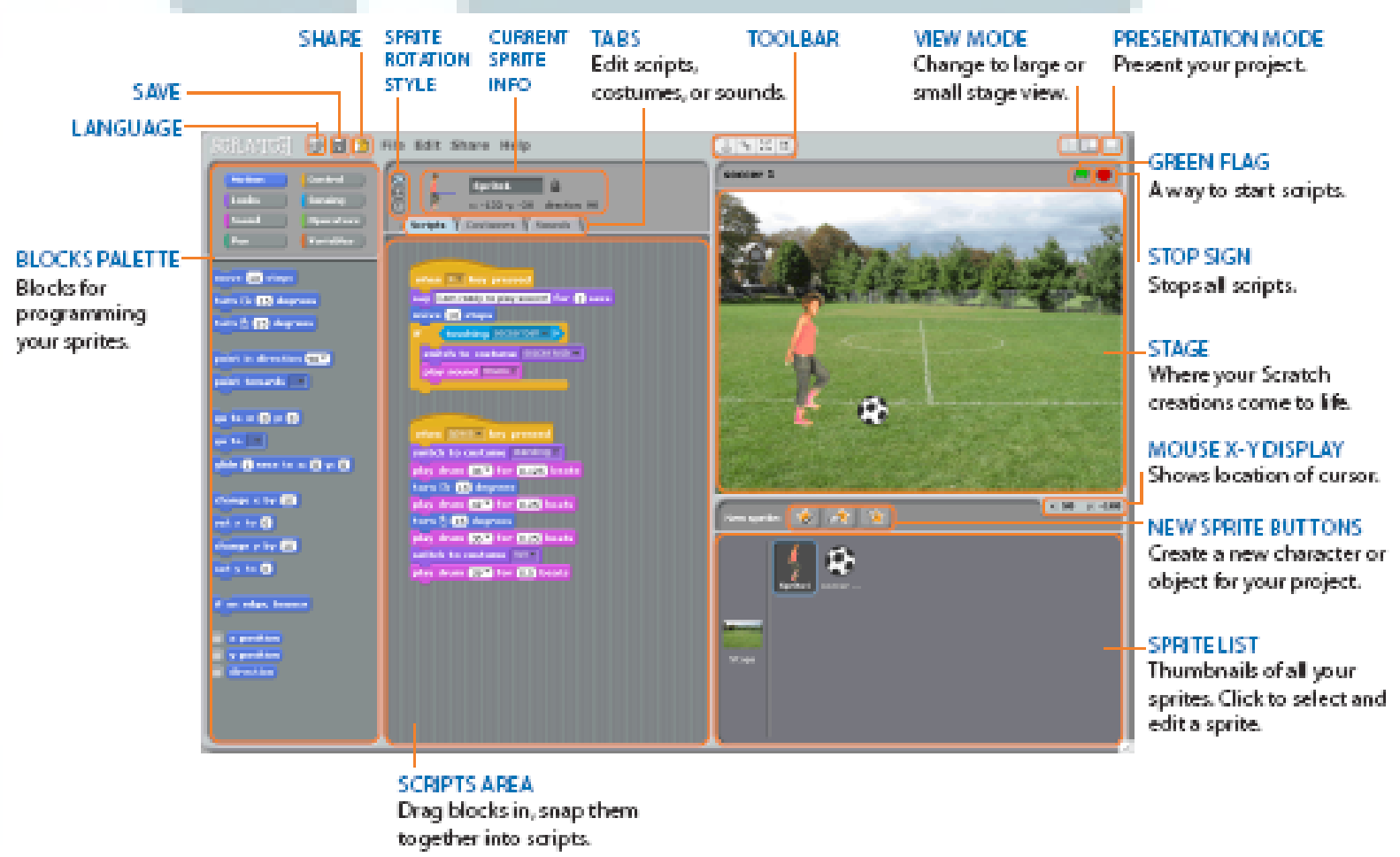

Gambar 5. Antarmuka lingkungan Scratch [9] 
ISSN 2085-4579

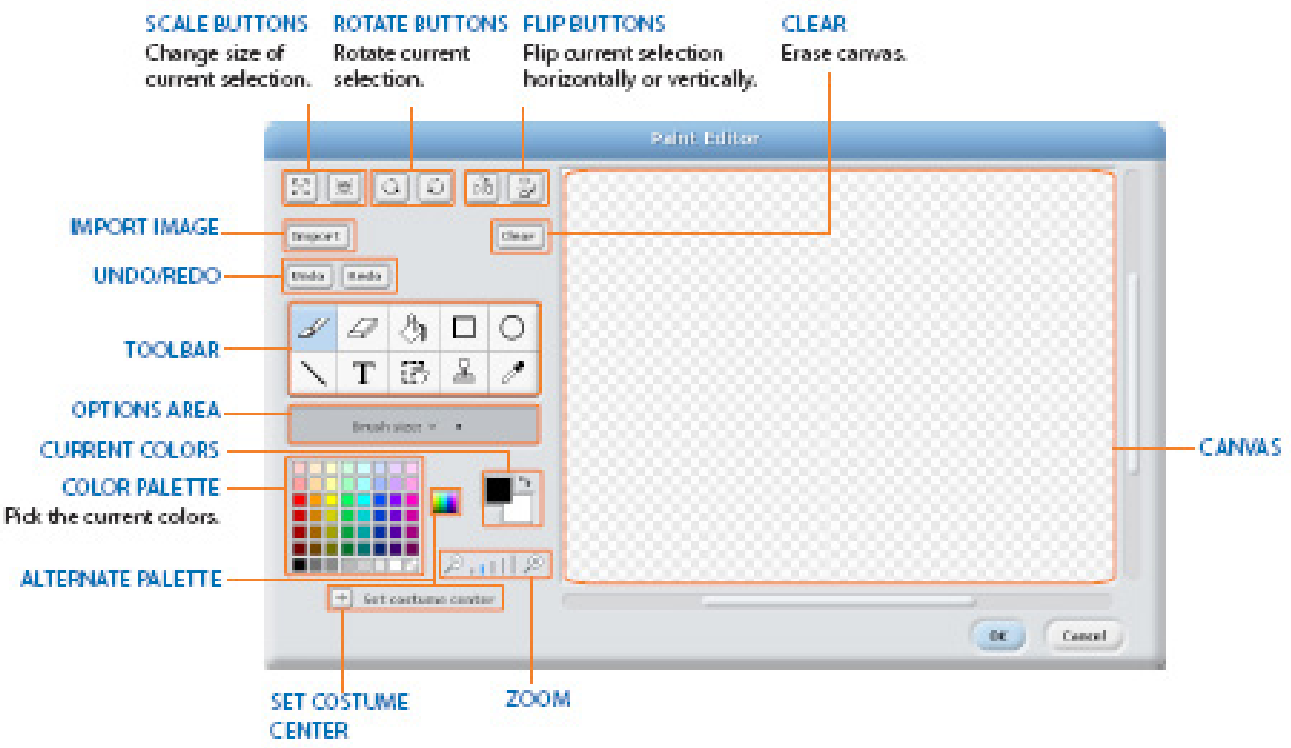

Gambar 6. Antarmuka Paint Editor untuk membuat atau meng-edit costumes dan backgrounds [9]

\section{Scratch Blocks}

Scratch blocks diorganisasi ke dalam delapan kategori warna berbeda, yakni Motion, Looks, Sound, Pen, Control, Sensing, Operators, dan Variables [9].

\begin{tabular}{|l|l|}
\hline Motion & Control \\
\hline Looks & Sensing \\
\hline Sound & Operators \\
\hline Pen & Variables \\
\hline
\end{tabular}

Gambar 7. Kategori Blocks

\section{Motion}

Block motion berisikan blok-blok yang dapat digunakan untuk menggerakkan sprites dalam project user.

\begin{tabular}{|c|c|}
\hline move 20 atops & Moves sprite forward or backward. \\
\hline turn of 15 degrees & Rotates sprite clockwise. \\
\hline turn 515 degrees & Rotates sprite counterclockwise. \\
\hline Eoint in direction 900 & $\begin{array}{l}\text { Points sprite in the specified direction. (10-up, } 90-\text {-ight } \\
\text { 180-domn -90-keft) }\end{array}$ \\
\hline
\end{tabular}

\begin{tabular}{|c|c|}
\hline paint tomards a & Points sprite toward mouse-pointer or another sprite. \\
\hline eotox: 0 y: 0 & Moves sprite to specified $\mathbf{x}$ and $\mathbf{y}$ position on Stage. \\
\hline goto to & $\begin{array}{l}\text { Moves sprite to the location of the mouse-pointer } \\
\text { or another sprite. }\end{array}$ \\
\hline ginde 1 esces to $x: 0$ y: 0 & $\begin{array}{l}\text { Moves sprite smoothly to a specified position over } \\
\text { specified length of time. }\end{array}$ \\
\hline Change $x$ by 10 & Changes sprite's x-position by specified amount. \\
\hline Eet $x$ to 0 & Sets sprite's $\mathrm{x}$-position to specified value. \\
\hline change y by do & Changes sprite's y-position by specified amount. \\
\hline Ect $y$ to 0 & Sets sprite's y-position to specified value. \\
\hline Af an edge, bounce & $\begin{array}{l}\text { Turns sprite in opposite direction when sprite touches } \\
\text { edge of Stage. }\end{array}$ \\
\hline E X position & Reports sprite's X-position. Psangesfrom -240 to 240 ) \\
\hline$\pi$ Cposition & Reports sprite's y-position. Ranges from-180 to 18m) \\
\hline E diraction & Reports sprite's direction. (10-up,90-right 180-down,-90-Jeft) \\
\hline
\end{tabular}

Selain itu, terdapat motor blocks yang dapat ditampilkan jika opsi 'Show Motor Blocks' dalam menu Edit dipilih.

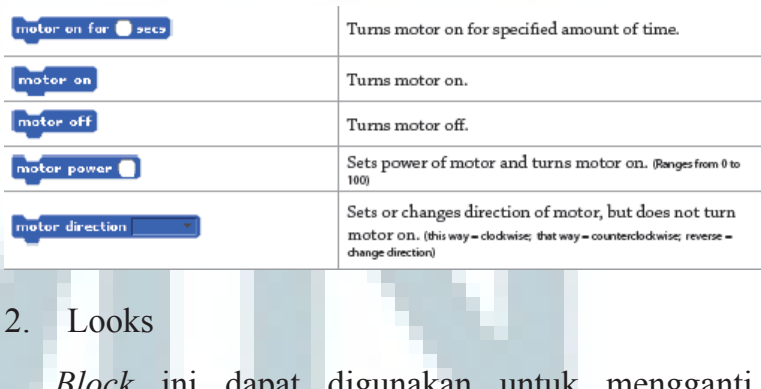
costume sprites, background stage, ukuran sprite, dan sebagainya.

\begin{tabular}{|c|c|}
\hline Emitch to costume costernes] & $\begin{array}{l}\text { Changes sprite's appearance by switching to different } \\
\text { costume. }\end{array}$ \\
\hline next costume & $\begin{array}{l}\text { Changes sprite's costume to next costume in the cos- } \\
\text { tume list. Afotend ofthe costume ix jumps becktof tirt cotume) }\end{array}$ \\
\hline$\square$ costume $\rightarrow$ & Reports sprite's current costume number. \\
\hline 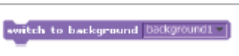 & $\begin{array}{l}\text { Changes Stage's appearance by switching to a different } \\
\text { background. }\end{array}$ \\
\hline
\end{tabular}




\begin{tabular}{|c|c|}
\hline mext backaround & $\begin{array}{l}\text { Changes Stage's background to next background in } \\
\text { the background list. }\end{array}$ \\
\hline m background $\Rightarrow$ & Reports Stage's current background number. \\
\hline हैy Hdd for $23 \mathrm{secs}$ & $\begin{array}{l}\text { Displays sprite's speech bubble for specified } \\
\text { amount of time. }\end{array}$ \\
\hline Eay Held & 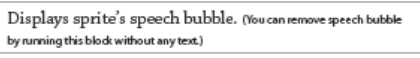 \\
\hline thenk Itrmin. for 2 seces & $\begin{array}{l}\text { Displays sprite's thought bubble for specified } \\
\text { ammont of time. }\end{array}$ \\
\hline think Htrmen. & Displays sprite's thought bubble. \\
\hline chinage als - effect by 23 & $\begin{array}{l}\text { Changes a visual effect on a sprite by specified amount. } \\
\text { (Na pulldonn merus to choose effect) }\end{array}$ \\
\hline Ext deder-fifect ta 0 & $\begin{array}{l}\text { Sets a visual effect to a given number. Mostrival effects range } \\
\text { form o to } 1000\end{array}$ \\
\hline Eleser graplaie affects & Clears all graphic effects for a sprite. \\
\hline chisage atize by \&o & Changes sprite's size by specified amount. \\
\hline Get size to too 00 & Sets sprite's size to specified \% of original size. \\
\hline I Give & Reports sprite's size, as \% of original size. \\
\hline thove & Makes sprite appear on the Stage. \\
\hline hide & 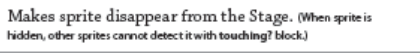 \\
\hline go to front & Moves sprite in front of all other sprites. \\
\hline go back (1) layares & $\begin{array}{l}\text { Moves sprite back a specified number of layers, so that } \\
\text { it can be hidden behind other sprites. }\end{array}$ \\
\hline
\end{tabular}

ISSN 2085-4579

\section{Sound}

Blok-blok yang mengatur penggunaan efek suara dapat ditemukan dalam sound block ini.

\begin{tabular}{|c|c|}
\hline \multicolumn{2}{|l|}{ Sound } \\
\hline Whay sound maver & $\begin{array}{l}\text { Starts playing a sound, selected from pull-down menu, } \\
\text { and immediately goes on to the next block even as } \\
\text { sound is still playing. }\end{array}$ \\
\hline Dolsy sound & $\begin{array}{l}\text { Plays a sound and waits until the sound is finished } \\
\text { playing before continuing with next block. }\end{array}$ \\
\hline Stop all sounds & Stops playing all sounds. \\
\hline Elay drum $48 \nabla$ for 02 beats & $\begin{array}{l}\text { Plays a drum sound, selected from pull-down menu, for } \\
\text { specified number of beats. }\end{array}$ \\
\hline Play note $60>$ for 09 haztc & $\begin{array}{l}\text { Plays a musical note highter rumbers br higherpitches) for speci- } \\
\text { fied number of beats. }\end{array}$ \\
\hline Fest for 0.2 beate & Rests (plays nothing) for specified number of beats. \\
\hline Eet instrument to 10 & $\begin{array}{l}\text { Sets the type of instrument that the sprite uses for } \\
\text { play note blocks. Each ppite has it orn instrunent) }\end{array}$ \\
\hline Ehronge volume by $(-10$ & $\begin{array}{l}\text { Changes sprite's sound volume by specified amount. } \\
\text { volume ranges from } 0 \text { to } 100 \text {. }\end{array}$ \\
\hline Eat volume to 100 of & Sets sprite's sound volume to specified value. \\
\hline Ev colume & Reports sprite's sound volume. \\
\hline Change tempo by 20 & Changes sprite's tempo by specified amount. \\
\hline Get teanpo to $60 \mathrm{hpm}$ & $\begin{array}{l}\text { Sets sprite's tempo to specified value in beats per } \\
\text { minute. }\end{array}$ \\
\hline E (empo & Reports sprite's tempo in beats per minute. \\
\hline
\end{tabular}

4. Pen

Mengatur penggunaan pen dan stamps di project.

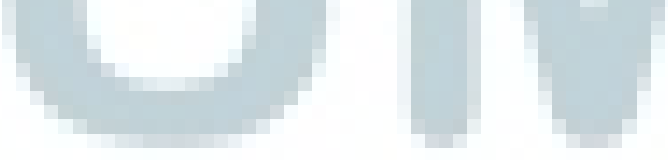

\begin{tabular}{|c|c|}
\hline \multicolumn{2}{|l|}{ Pen } \\
\hline dear & Clears all pen marks and stamps from the Stage. \\
\hline peren down & Puts down sprite's pen, so it will draw as it moves. \\
\hline pen up & Pulls up sprite's pen, so it won't draw as it moves. \\
\hline Eet pen color to & $\begin{array}{l}\text { Sets pen's color, based on choice from color picker. } \\
\text { Fiding the color also changes the pen shade. }\end{array}$ \\
\hline Change pen eolor by 10 & Changes pen's color by specified amount. \\
\hline Eet pen color to 0 & 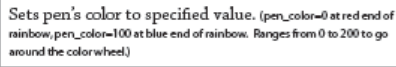 \\
\hline Change pen shade by to & Changes pen's shade by specified amount. \\
\hline Eet pen shade to 50 & 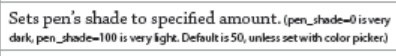 \\
\hline Change pen size by 0 & Changes pen's thickness. \\
\hline Bet pen size to 10 & Sets pen's thickness. \\
\hline Etamp & Stamps sprite's image onto the Stage. \\
\hline
\end{tabular}

\section{Control}

Blok ini berisikan sejumlah blok utama script agar dijalankan dan blok struktur kendali.

\begin{tabular}{|l|l|}
\hline Runs script below when green flag is clicked. \\
\hline Runs script below when specified key is pressed. \\
\hline Runs script below when sprite is clicked. \\
\hline Waits specified number of seconds, then continues \\
with next block.
\end{tabular}

6. Sensing

Terkait hal-hal yang dapat dikerjakan sprites.

\begin{tabular}{|c|c|}
\hline \multicolumn{2}{|l|}{ Sensing } \\
\hline touching ए? & $\begin{array}{l}\text { Reports true if sprite is touching specified sprite, edge, } \\
\text { or mouse-pointer. Select frompul-down menuJ }\end{array}$ \\
\hline touching color E? & $\begin{array}{l}\text { Reports true if sprite is touching specified color. (Iick on } \\
\text { cobr patch then use eredopper to selest cdoc) }\end{array}$ \\
\hline color [is touching $[$ ? & $\begin{array}{l}\text { Reports true if first color (within sprite) is touching } \\
\text { second color (in background or another sprite). (Cikkon } \\
\text { cobrp patch then Use eyedopper to selest cdor) }\end{array}$ \\
\hline
\end{tabular}


ISSN 2085-4579

\begin{tabular}{|c|c|}
\hline acke $\square$ and wait & $\begin{array}{l}\text { Asks a question on the screen and stores keyboard } \\
\text { input in the } \\
\text { the Enter key is pressed or check mark is clicked. }\end{array}$ \\
\hline In encover & $\begin{array}{l}\text { Reports keyboard input from the most recent use of } \\
\text { and wait. Shred by all sprites glocbol. }\end{array}$ \\
\hline mouse $x$ & Reports the $x$-position of mouse-pointer. \\
\hline mouse y & Reports the y-position of mouse-pointer. \\
\hline mouse down? & Reports true if mouse button is pressed. \\
\hline Gey Ep:Ser - pressed? & Reports true if specified key is pressed. \\
\hline distance to lo & $\begin{array}{l}\text { Reports distance from the specified sprite or } \\
\text { mouse-pointer. }\end{array}$ \\
\hline reset timer & Sets the timer to zero. \\
\hline It Gimer & $\begin{array}{l}\text { Reports the value of the timer in seconds. The timeris } \\
\text { stroyssunning) }\end{array}$ \\
\hline Apreztion - of Sprital - & Reports a property or variable of another sprite. \\
\hline Ir loudness & $\begin{array}{l}\text { Reports the volume (from } 1 \text { to } 100 \text { ) of sounds detected } \\
\text { by the computer microphone. }\end{array}$ \\
\hline It bud? & $\begin{array}{l}\text { Reports true if computer microphone detects a sound } \\
\text { volume greater than } 30 \text { (on scale of } 1 \text { to } 100) \text {. }\end{array}$ \\
\hline II Gider sensor value & 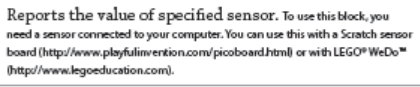 \\
\hline [1 Gensor [butten pressed - ? & 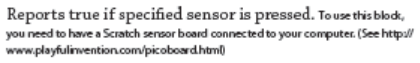 \\
\hline
\end{tabular}

\section{Operators}

Berisi berbagai operator aritmatika yang dapat digunakan dalam project.

\begin{tabular}{|c|c|}
\hline Operators & \\
\hline $\mathbf{O}+\mathbf{0}$ & Adds two numbers. \\
\hline Q. & Subtracts second number from first number. \\
\hline 0 & Multiplies two numbers. \\
\hline O & Divides first number by second number. \\
\hline pick random 1 to 10 & Picks a random integer within the specified range. \\
\hline $\mathbf{0} \times \mathbf{O}$ & Reports true if first value is less than second. \\
\hline $0=0$ & Reports true if two values are equal. \\
\hline $\mathbf{0}>\mathbf{0}$ & Reports true if first value is greater than second. \\
\hline$\varnothing$ and - & Reports true if both conditions are true. \\
\hline or 0 & Reports true if either condition is true. \\
\hline not 6 & $\begin{array}{l}\text { Reports true if condition is false; reports false if } \\
\text { condition is true. }\end{array}$ \\
\hline Foin ID & Concatenates (combines) strings. \\
\hline length of & Reports the number of letters in a string. \\
\hline letter Dof D & Reports the letter at the specified position in a string. \\
\hline बख्यात of 10 & 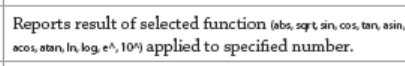 \\
\hline Cmod & $\begin{array}{l}\text { Reports remainder from division of first number by } \\
\text { second number. }\end{array}$ \\
\hline Found $\mathbf{O}$ & Reports closest integer to a number. \\
\hline
\end{tabular}

Berisi blok-blok yang dapat digunakan untuk membuat variabel dan list, maupun menghapusnya.

\begin{tabular}{|c|c|}
\hline Variables & \\
\hline Make a variable & 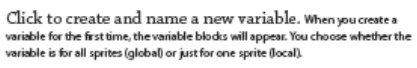 \\
\hline Delete a variable & Deletes all blocks associated with a variable. \\
\hline In Gcore & Reports value of the variable. \\
\hline change sorer by 1 & 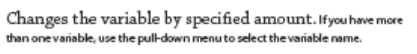 \\
\hline set Beore to 0 & Sets the variable to specified value. \\
\hline thow variable ererav & Shows the variable monitor on the stage. \\
\hline hiule variable ecceren & $\begin{array}{l}\text { Hides the variable monitor so it is not visible on the } \\
\text { stage. }\end{array}$ \\
\hline Make a list & 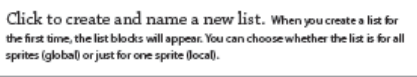 \\
\hline Delete a list & Deletes the blocks associated with the list. \\
\hline Imy lise & 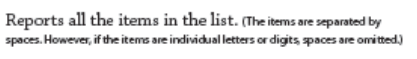 \\
\hline 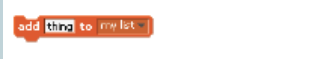 & $\begin{array}{l}\text { Adds the specified item to the end of the list. The item con } \\
\text { be a sumber or o atimg of letters and other charasters }\end{array}$ \\
\hline delete 17 of [rs liet & 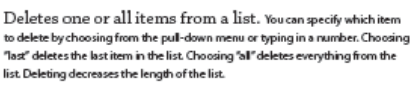 \\
\hline insert thing at 17 of meylint & 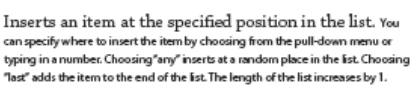 \\
\hline replece item [17 of my Ist - with thing & 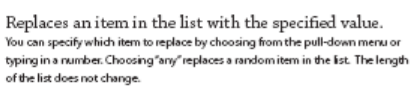 \\
\hline fitem $1>$ of $m$ my lat & 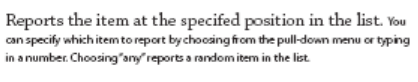 \\
\hline 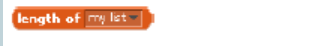 & Reports how many items are in the list. \\
\hline IEE cantains thing & $\begin{array}{l}\text { Reports true if the list contains the specified item. The } \\
\text { tem nus matcheosxaty to report tue. }\end{array}$ \\
\hline
\end{tabular}

\section{Ping Pong Game}

Sebagaimana yang telah dijelaskan dalam bab Pendahuluan, Scratch dapat digunakan untuk membuat game interaktif. Menurut Sadigh [10], terdapat lima elemen utama dari suatu permainan komputer, yakni graphics (grafik), sound (suara), interface (antarmuka), gameplay (alur permainan), dan story (kisah). Scratch dengan grafik 2D dan efek suara yang didukungnya, antarmuka yang interaktif, serta gameplay dan story yang dapat dengan mudah diatur oleh programmer-nya menggunakan blok-blok yang disediakan, dapat menjawab seluruh kebutuhan elemen dalam permainan komputer tersebut.

Berikut disajikan salah satu contoh permainan interaktif populer, yakni Ping Pong game, yang dibuat dengan menggunakan Scratch. Permainan ini dibuat oleh salah seorang Scratcher dengan nama alias kingminer29, dan dapat dimainkan secara langsung melalui tautan http://scratch.mit.edu/projects/ 22791282/?fromexplore=true [11]. 


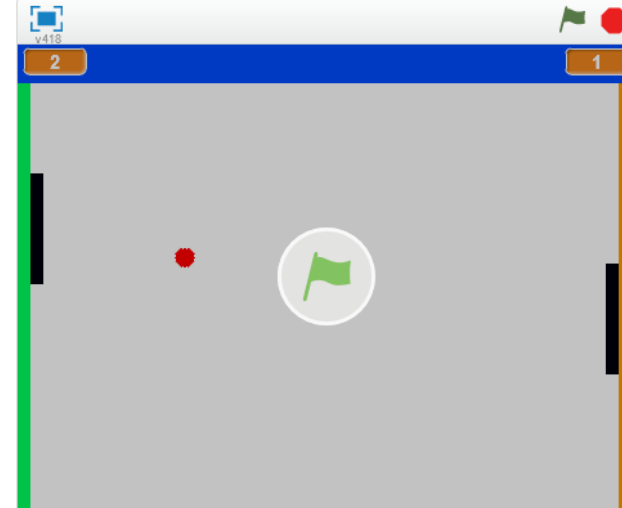

Gambar 8. Laman awal permainan ping pong

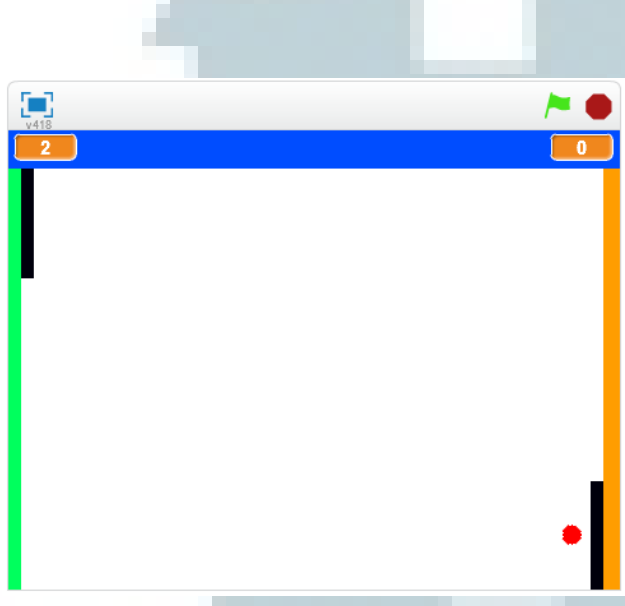

Gambar 9. Permainan ping pong antara dua pemain

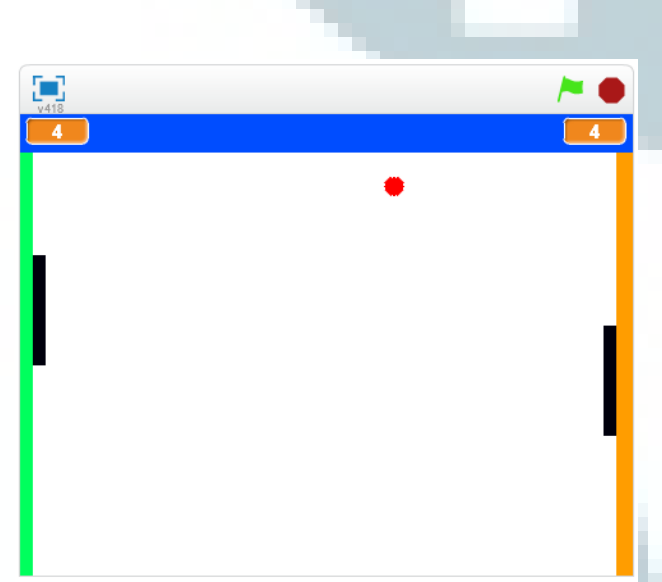

Gambar 10. Bola ping pong memantul sepanjang dinding meja permainan

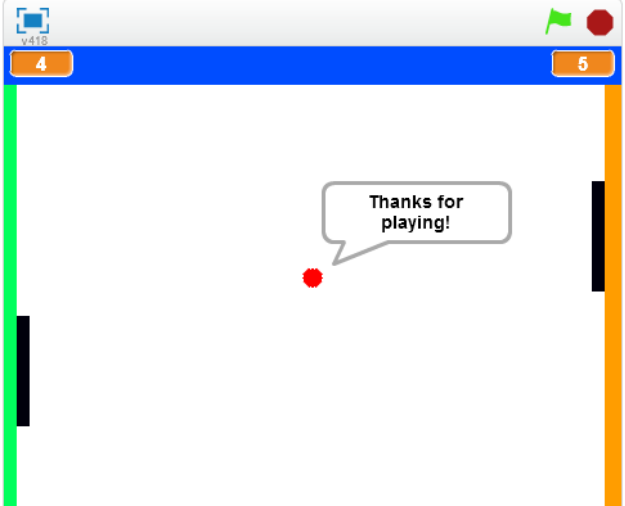

Gambar 11. Permainan berakhir saat salah seorang pemain memperoleh skor 5

Selain permainan interaktif, Scratch juga dapat digunakan untuk membuat beragam aplikasi lainnya, seperti animasi, seni, musik, cerita, dan sebagainya. Kumpulan projects yang telah dihasilkan dapat dilihat pada situs resmi Scratch secara langsung [12].

\section{Simpulan}

Scratch sebagai bahasa pemrograman visual yang populer menawarkan sejumlah kemudahan dan fitur yang menarik bagi para pemula dalam mempelajari cara pemrograman. Bahkan sejumlah sekolah menengah atas dan universitas (termasuk Harvard dan University of California, Berkeley) juga telah menggunakan Scratch sebagai langkah pertama dalam memperkenalkan konsep pemrograman kepada para peserta didiknya [13].

Dalam makalah ini, sejarah perkembangan, antarmuka dan blok pembangun sebagai konsep dasar yang perlu diketahui oleh para pemula Scratch telah dijelaskan. Salah satu contoh permainan interaktif yang dikembangkan dengan menggunakan Scratch juga telah diperlihatkan. Dengan demikian, diharapkan dapat memberikan gambaran kepada para pembaca mengenai cara pemanfaatan dan pentingnya Scratch dalam budaya komputasional yang dihadapi oleh manusia masa kini.

\section{Daftar Pustaka}

[1] Getting Started with SCRATCH Version 1.4, http://scratch. mit.edu, Lifelong Kindergarten Group, MIT Media Lab.

[2] http://scratch.mit.edu/educators/, diakses 27 Mei 2014.

[3] http://scratched.media.mit.edu/, diakses 27 Mei 2014.

[4] Brennan, K.A., 2013, Best of Both Worlds: Issues of Structure and Agency in Computational Creation, In and Out of School, Dissertation, School of Architecture and Planning, Massachusetts Institute of Technology.

[5] Chiang, J., Shall We Learn Scratch Programming, http:// shallwelearn.com.

[6] http://wiki.scratch.mit.edu/wiki/Development_of_ 
Scratch_1.0, diakses 27 Mei 2014.

[7] http://wiki.scratch.mit.edu/wiki/Scratch_Versions, diakses 27 Mei 2014.

[8] http://scratch.mit.edu/statistics/, diakses 27 Mei 2014.

[9] Reference Guide: Scratch Version 1.4, http://scratch.mit.edu, Lifelong Kindergarten Group, MIT Media Lab.

[10] Sadigh, M., 2002, How to Design a Computer Game?, Final Project, University of Washington.

[11] http://scratch.mit.edu/projects/22791282/?fromexplore=true, diakses 28 Mei 2014.

[12] http://scratch.mit.edu/explore, diakses 28 Mei 2014.

[13] Resnick, M., Maloney, J., Monroy-Hernandez, A., Rusk, N., Eastmond, E., Brennan, K., Millner, A., Rosenbaum, E., Silver, J., Silverman, B., and Kafai, Y., Scratch: Programming for All, Communications of the ACM, Vol. 52, No. 11, November 2009.
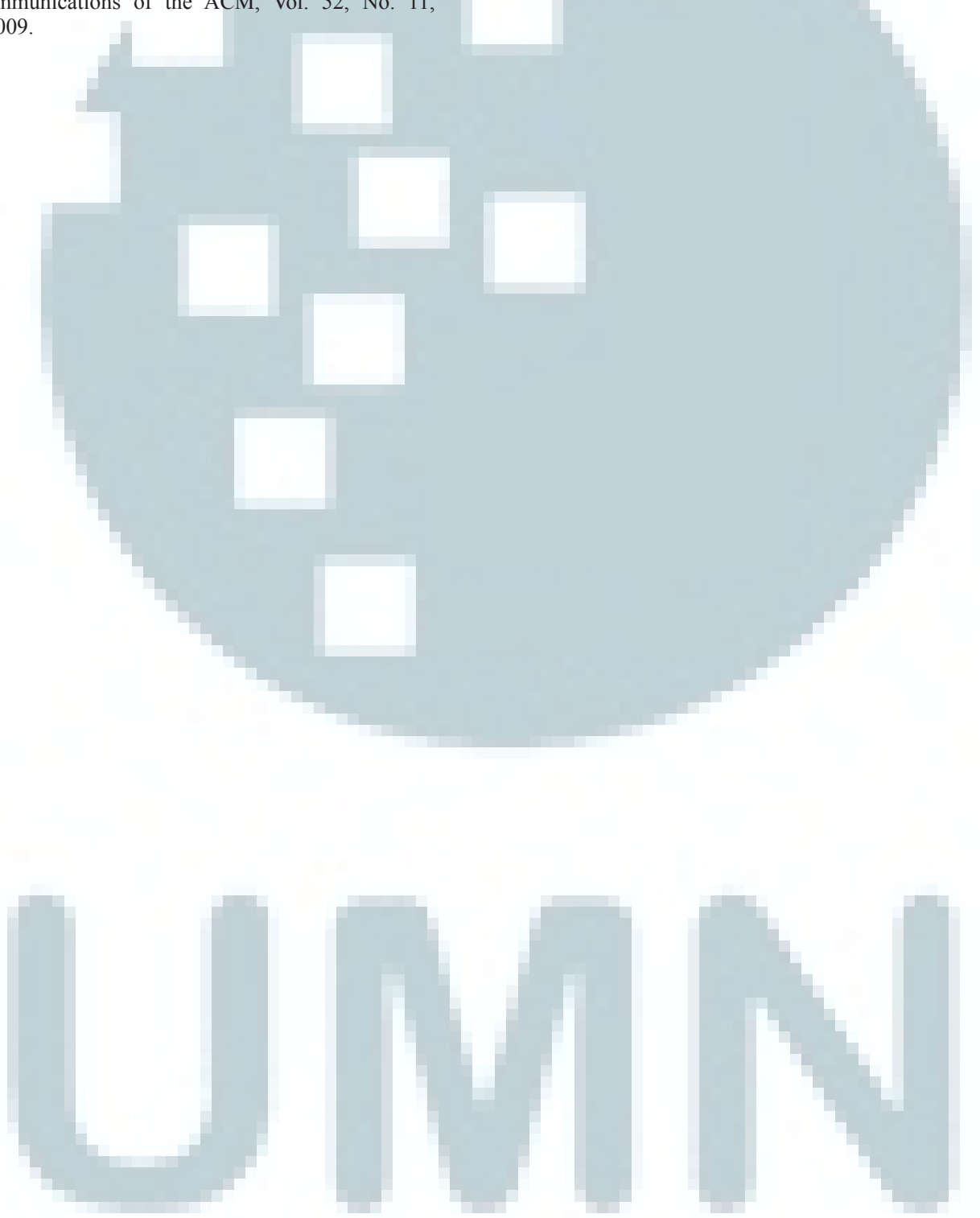